\title{
MATERIALNOŚĆ ŚWIETLNEGO ZAPISU - O RZECZACH W DOROBKU JERZEGO LEWCZYŃSKIEGO ${ }^{1}$
}

\author{
będę siedział \\ nieruchomy \\ zapatrzony \\ w serce rzeczy \\ Zbigniew Herbert, Objawienie (1961)
}

\section{FOTOGRAFIA JAKO RZECZ}

Szeroki wachlarz nowych możliwości interpretacyjnych, który antropologia rzeczy ${ }^{2}$ rozpostarła przed historią sztuki, jawi się jako wciąż nie w pełni wykorzystany w badaniach nad polską fotografią powojenną ${ }^{3}$. W dotychczasowej literaturze przedmiotu nacisk kładziono bowiem raczej na potencjał imperatywu konceptualnego, w którym to materialny wymiar konkretnych artefaktów ustępuje miejsca potędze samej idei twórczej. Kluczowe dla tego

1 Tekst ten stanowi pokłosie badań prowadzonych między innymi w ramach indywidualnego stypendium twórczego z budżetu Ministra Kultury i Dziedzictwa Narodowego (2017).

${ }^{2}$ Choć Agata Zborowska sygnalizuje, że trudno dziś mówić o jednym sposobie rozumienia tego ruchu (ze względu na duże zróżnicowanie podejść i rozdźwięk w rozumieniu nawet podstawowej terminologii), to w niniejszym tekście wychodzę - podobnie jak Graham Harman, Elizabeth Edwards czy Bjørnar Olsen - z myśli Bruno Latoura, stanowiącej podstawę dla wielu teorii zorientowanych na rzeczy; por. A. Zborowska, Przedmioty W działaniu, „Widok. Teorie i praktyki kultury wizualnej” 2014, 6, <http://pismowidok. org/index.php/one/article/view/200/330> [dostęp: 5 lutego 2018].

${ }^{3}$ Znakomitą próbą przełamania status quo była publikacja Magdaleny Wróblewskiej, jednak zawarte w niej obserwacje na temat fotografii Ewy Faryaszewskiej z czasu powstania warszawskiego nie zostały podjęte przy analizach innych obszarów polskiej fotografii; por. M. Wróblewska, Fotografie ruin, ruiny fotografii 1944-2014, Warszawa 2014. 
okresu dzieło - słusznie ciesząca się nieustannym zainteresowaniem badaczy Ikonosfera I (1967) Zbigniewa Dłubaka (1921-2005) - była pojmowana przede wszystkim jako znaczący moment fotomedialnego przełomu; preludium, którego echa miały pobrzmiewać między innymi w późniejszych działaniach grupy PERMAFO. Znaczenie tej instalacji ujmowano przeważnie w kategoriach bezprecedensowego na polskim gruncie zaaranżowania przestrzeni ${ }^{4}$; wobec imponującego novum environment, fizyczny wymiar jednostkowych zdjęć pozostawał w cieniu innych aspektów dzieła, uchodzących za bardziej spektakularne. Warto jednak podkreślić, że sięgnięcie po prace teoretyków związanych z tak zwanym gestural collective $e^{5}$ do którego należą między innymi Geoffrey Batchen ${ }^{6}$, Elizabeth Edwards ${ }^{7}$ czy Chris Morton ${ }^{8}$ - umożliwia zupełnie nowe spojrzenie na tę, kanoniczną już, pracę Dłubaka. Wzmiankowani badacze przeciwstawiają się (wciąż powszechnemu) rozumieniu fotografii jako pozbawionej ciała i formy reprezentacji i podkreślają niejednorodność specyfiki obiektów, jakie możemy wpisać w ramy tego medium ${ }^{9}$. Elizabeth Edwards ${ }^{10}$ zdecydowanie odrzuca redukcjonistyczną wizję Rogera Scrutona ${ }^{11}$, w której zdjęcia nie są rzeczami (o określonym formacie i ciężarze, swoistej strukturze powierzchni czy nawet - zapachu), ale surogatami - abstrakcyjnymi jakościami wizualnymi. W perspektywie programu ukierunkowanego

${ }^{4}$ Przykładowe analizy Ikonosfery I, por. K. Ziębińska (Lewandowska), „Praktyka widzenia. Twórczość fotograficzna Zbigniewa Dłubaka w latach 1947-2000”, praca magisterska napisana pod kierunkiem prof. Marii Poprzęckiej, Instytut Historii Sztuki Uniwersytetu Warszawskiego, Warszawa 2001, s. 45-48; A. Zagrodzka, Fotografia subiektywna w sztuce polskiej 1956-1969, Lublin 2016, s. 15-18; A. Sobota, Nowe horyzonty w nowych mediach. Zjawiska sztuki polskiej w latach 1945-1981, Wrocław 2017, s. 180.

${ }^{5}$ O. Sibum, Reworking the mechanical value of heat: instruments of precision and gestures of accuracy in early Victorian England, "Studies in History and Philosophy of Science" $1995,1(26)$, s. 77.

${ }^{6}$ G. Batchen, Each wild idea. Writing, photography, history, London 2000, s. 28-33, 61.

7 E. Edwards, Photography and the material performance of the past, „History and Theory" 2009, 4(48), s. 131-135.

8 C. Morton, Photography and the comparative method: the construction of an anthropological archive, „Journal of the Royal Anthropological Institute" 2012, 2(18), s. $376-$ 380, 386-389.

9 Syntetyczny zarys różnorodnych praktyk por. E. Edwards, Objects of affect: photography beyond the image, „Annual Review of Anthropology” 2012, 41, s. 225-228.

10 Dziękuję Pani Profesor Edwards za inspirującą rozmowę podczas konferencji „Diverse migrations: photography out of bounds", zorganizowanej przez The Photographic History Research Centre (De Montfort University, 19-20 czerwca 2017).

${ }^{11}$ R. Scruton, Fotografia i reprezentacja, w: Fotografia i filozofia. Szkice o pędzlu natury, red. S. Walden, tłum. I. Zwiech, Kraków 2013, s. 188-191. 
na badanie materialnego komponentu fotografii wydaje się wart odnotowania fakt, że Dłubak w ramach Ikonosfery I radykalnie odszedł od klasycznego pokazywania zdjęć jako dzieł unieruchomionych w depersonalizującym passe-partout i antyramie ${ }^{12}$. Twórca celowo przecież zawieszał swoje prace, przytwierdzając tylko ich górne rogi (il. 1). „Pozorując swobodę roboczego pokazu w pracowni"13 - jak pisała Urszula Czartoryska - Dłubak dokonał swego rodzaju desakralizacji sztuki - podkreślił, że zdjęcia przynależą do porządku codzienności. Naruszył on strukturę autorskich odbitek (bezpośrednio mocując je do czarnych ścianek ustawionych w warszawskiej Galerii Współczesnej), zarazem umożliwiając im swobodne powiewanie pod wpływem pędu powietrza, wytwarzanego przez specjalnie w tym celu ustawione wiatraczki i ruch samych zwiedzających. Skonfrontowani z fotograficznym labiryntem odbiorcy przestawali być neutralnymi obserwatorami. Ich fizyczna obecność w przestrzeni ekspozycyjnej potęgowała kreowanie spektaklu znaczeń poprzez stopniowe niszczenie samych zdjęć. Wraz z upływem czasu odbitki wykorzystane w instalacji coraz silniej zaginały się i zwijały, ze szkodą dla widoczności przedstawionych na nich scen. Koncepcja fotografii jako namacalnej rzeczy - wrażliwej na warunki ekspozycji, ulegającej przeobrażeniom i uczestniczącej w różnego rodzaju praktykach cielesnych - okazuje się jedną z niezaprzeczalnych, choć dotąd niewydobytych, wartości projektu Dłubaka. Co więcej, poprzez brutalne wyrwanie zdjęć z legitymizujących ich pozycję w ówczesnym „art worldzie” ${ }^{14}$ obramowań (takich jak schludna oprawa czy harmonijne rozlokowanie w przestrzeni wystawienniczej w uporządkowanych sekwencjach ${ }^{15}$ ), ta niezwykle istotna dla powojennego środowiska fotograficznego postać wytyczyła zupełnie nowe ścieżki działań artystycznych. Dłubak sprowokował współczesnych do postawienia doniosłego pytania: „czy po Ikonosferze da się już fotografować tak, jak robiliśmy to dotychczas?”"16.

12 Późniejsze alternatywy dla „zastygłych, formalnych systemów”, por. M. Lachowski, Awangarda wobec instytucji. O sposobach prezentacji sztuki w PRL-u, Lublin 2006.

${ }^{13}$ U. Czartoryska, Ikonosfera Zbigniewa Dłubaka, „Fotografia” 1967, 5, s. 101.

${ }^{14}$ Fotografia polska w początkach lat 60 . XX wieku wciąż zmagała się z koniecznością uzyskania nobilitującego statusu „sztuki plastycznej”. O napięciu między artystami a fotografami i potrzebie uznania tych ostatnich w świecie sztuki świadczą choćby relacje prasowe, podsumowujące XII Ogólnopolską Wystawę Fotografiki, por. np. J. Kuryluk, O mistrzach obiektywu - obiektywnie, „Kamena” 1962, 15(253), s. 7.

15 Schematu tego, widocznego na przykład na II Ogólnopolskiej Wystawie Fotografiki (1952, gmach Zachęty, Warszawa), nie udało się w pełni przełamać nawet za sprawą bardzo ambitnego projektu scenograficznego Wojciecha Zamecznika (1923-1967) dla - 10 lat późniejszej - XII Ogólnopolskiej Wystawy Fotografiki (1962, gmach Zachęty, Warszawa).

${ }^{16}$ J. Garztecki, Prowokacje, „Kultura” 1967, 18(248), s. 10. 


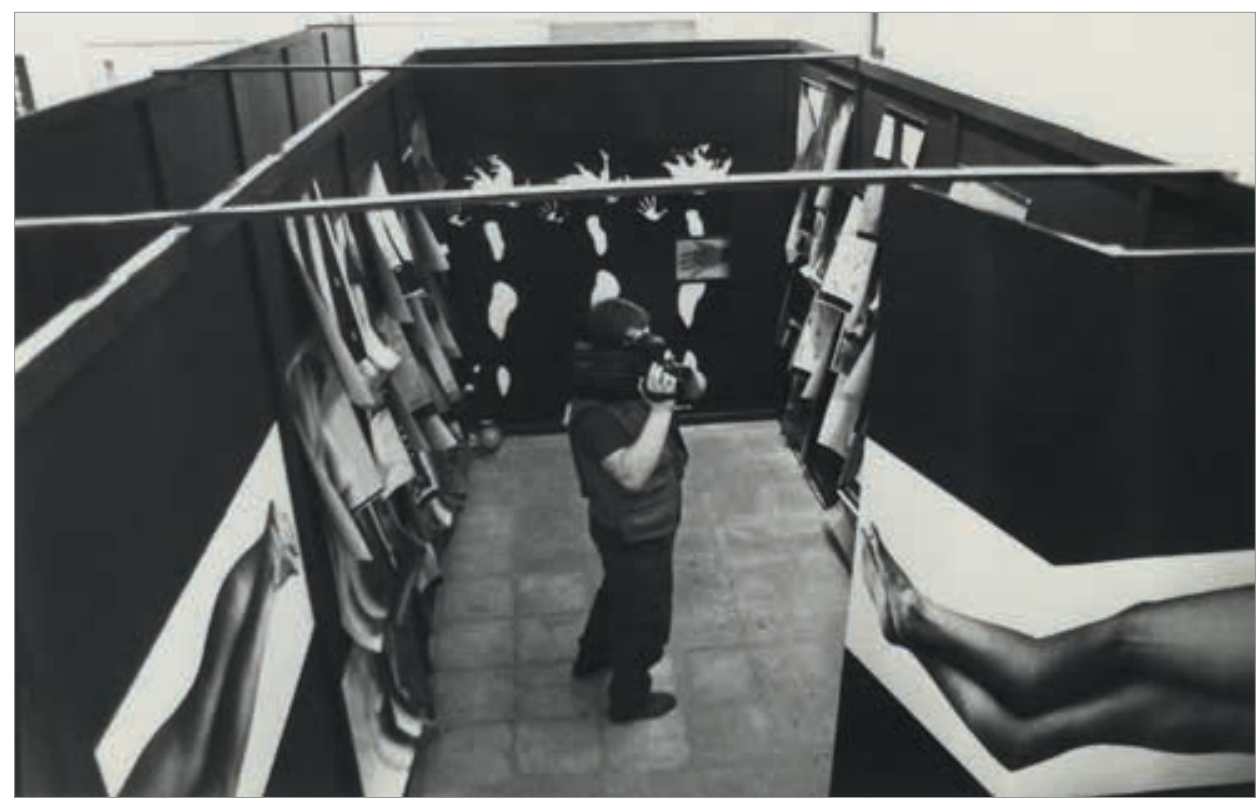

1. Elżbieta Tejchman, widok instalacji Zbigniewa Dłubaka Ikonosfera I w Galerii Współczesnej w Warszawie, 1967, czarno-biała odbitka żelatynowo-srebrowa, nr inw. 01-A-0400996(1). Dzięki uprzejmości W. Wawrzonowskiego i Fundacji Archeologia Fotografii

Nie bez powodu stanowiące główny temat niniejszego artykułu rozważania poświęcone koncepcji Jerzego Lewczyńskiego (1924-2014) rozpoczyna właśnie dygresja na temat Zbigniewa Dłubaka. Ich sylwetki zostały uznane za fundamentalne dla polskiej historii sztuki ${ }^{17}$, możliwe jest też wytyczenie punktów łączących ich praktyki artystyczne ${ }^{18}$, a ponadto wiązała ich serdeczna, koleżeńska znajomość ${ }^{19}$. Mimo to nie wyznaczono dotych-

17 Ich status zdają się poświadczać liczne wystawy i katalogi poświęcone ich twórczości.

${ }_{18}$ Warto nadmienić, że jedna z wystaw Jerzego Lewczyńskiego i Zdzisława Beksińskiego opierała się na podobnym jak w Ikonosferze I zabiegu - artyści chaotycznie porozwieszali swoje prace na sznurku tworzącym skomplikowaną sieć w przestrzeni galerii (por. anonimowe zdjęcie pokazujące widok niezidentyfikowanej wystawy Z. Beksińskiego i J. Lewczyńskiego, depozyt Fundacji Archeologia Fotografii, nr inw. 06-A-02-00276). Ponadto Lewczyński żywo interesował się koncepcjami Dłubaka i przechowywał różne materiały dotyczące jego działalności (por. J. Garztecki, „Próby myśli względnie uporządkowanych. Tezy estetyczne Zbigniewa Dłubaka", maszynopis, 9 maja 1981, w zbiorach Fundacji Asymetria w Warszawie).

19 Potwierdzają to: korespondencja (np. list J. Lewczyńskiego do Z. Beksińskiego z roku 1967, w zbiorach Muzeum Historycznego w Sanoku oraz list Beksińskiego do Lewczyńskiego z dn. 3 marca 1971, w zbiorach Muzeum w Gliwicach), zapiski (np. J. Lewczyński, „Oce- 
czas wspólnej platformy dla tych dwóch niezwykłych indywidualności twórczych. Niniejsze studium stanowi próbę przełamania symptomatycznej dla współczesnych badań trudności w konstruowaniu metodologicznej płaszczyzny, umożliwiającej symultaniczne rozpatrywanie (i konfrontowanie) dorobku kluczowych polskich fotografów powojennych ${ }^{20}$. Proponowana w tekście analiza strategii Jerzego Lewczyńskiego zakłada swego rodzaju „intencję"21 (sprawczość) fotografii, która wynika z jej materialnych cech; ów metodologiczny pryzmat umożliwi też dostrzeżenie nowych aspektów prac Zbigniewa Dłubaka czy Stefana Wojneckiego (ur. 1929). Wciąż nie w pełni naszkicowany, a drzemiący u źródeł koncepcji Lewczyńskiego, potencjał teoretyczny być może w przyszłości stanowić będzie katalizator do odkrycia na nowo oeuvre również takich twórców, jak Zdzisław Beksiński (1929-2005) ${ }^{22}$, Marek Piasecki (1935-2011)23 czy Zofia Rydet (1911-1997)24. Przedstawione w niniej-

an", odręczna notatka poświęcona realizacji Zbigniewa Dłubaka, 2 lutego 1973, w zbiorach Fundacji Asymetria w Warszawie) oraz fotografie (np. J. Lewczyński, Portret przyjaciela Zbigniewa Dłubaka, 2001, Muzeum Historii Fotografii w Krakowie, fotomontaż, czarno-biała odbitka żelatynowo-srebrowa, nr inw. MHF 23481/II).

${ }^{20}$ Dłubak i Lewczyński byli dotąd prezentowani jako bardzo sobie odległe postaci, por. J. Kordjak-Piotrowska, Polska fotografia awangardowa 2. połowy lat 50., w: Egzystencje, red. R. Szwander, Warszawa 2005, s. 6-7; Sobota, Nowe horyzonty w nowych..., s. 180, 202.

${ }^{21}$ B. Olsen, Z. Dziuban, Wszyscy jesteśmy archeologami, „Znak”, wrzesień 2015, <http://www.miesiecznik.znak.com.pl/wszyscy-jestesmy-archeologami> [dostęp: 5 lutego 2018].

${ }^{22}$ Fotograficzne działania Zdzisława Beksińskiego rozpatrywano w kategoriach naśladownictwa estetyki Wielkiej Awangardy, neorealizmu czy plastycznego odbicia filozofii egzystencji, por. W. Kobylińska-Bunsch, „Fotografia egzystencjalna” Zdzisława Beksińskiego, „Miejsce. Studia nad sztuką i architekturą polską XX i XXI wieku” 2016, 2, s. 59-83. Przechowywane w zbiorach Muzeum Historycznego w Sanoku albumy ze zdjęciami wklejanymi na różowe karty otwierają jednak zupełnie nowe, pełne potencjału pole interpretacyine. Dyrekcji i pracownikom Muzeum Historycznego w Sanoku składam podziękowania za zgodę na przeprowadzenie kwerendy w roku 2013 i umożliwienie mi zapoznania się z tymi ciekawymi materiałami.

${ }_{23}$ O sylwetce Marka Piaseckiego powstało wiele tekstów pióra znakomitych krytyków i historyków sztuki, wciąż nie powstała jednak poświęcona temu artyście syntetyczna monografia, która z całą mocą podkreślałaby materialny wymiar jego dzieł fotograficznych. Najnowsza pozycja, stanowiąca cenne podsumowanie dotychczasowych informacji, została wydana staraniem Fundacji 9/11 Art Space, por. Marek Piasecki. With care, red. E. Chorzępa, M. Piłakowska, Poznań 2017.

${ }^{24}$ Ta wybitna postać jest nieustannie przywoływana w literaturze przedmiotu, ale wciąż nie wydobyto haptycznego aspektu jej prac (np. specyfiki fotomontaży czy "foto-rzeźb”|. Subtelnie zasygnalizowano to zjawisko na wystawie „Zofia Rydet. Zapis, 1978- 
szym tekście trzy zupełnie różne działania twórcze Lewczyńskiego posłużą zilustrowaniu silnie uobecniającego się w jego dorobku problemu rzeczy ${ }^{25}$.

\section{PROCES DESTRUKCJI - PARADOKSALNE ŚWIADECTWO ŻYCIA RZECZY}

Jerzy Lewczyński podkreślał, że fotografia - świadek przeszłości ${ }^{26}$ - to obiekt przede wszystkim materialny, kruchy i delikatny, a zatem narażony na rozkład. Zdjęcia pokrywa nie tylko symboliczna patyna czasu, ale są na nich widoczne ślady ich własnej historii, w postaci chemicznych i fizycznych zniszczeń ${ }^{27}$. Potwierdzają to między innymi prace Lewczyńskiego z cyklu Znalezione fotografie (il. 2$)^{28}$. W serii tej dokonuje on arbitralnej transpozycji obiektów ze sfery wernakularnej ${ }^{29}$ (amatorskiej, prywatnej, rodzinnej) w celu skonstruowania pewnej - jak ujęła to Maria Gołaszewska - „sytuacji estetycznej"30. Wybrane przez Lewczyńskiego zdjęcia naznaczone są charak-

1990” w Muzeum Sztuki Nowoczesnej w Warszawie (25 września 2015 - 10 stycznia 2016, kuratorzy: Sebastian Cichocki, Karol Hordziej), zasadniczo nacisk położono jednak na zupełnie inne właściwości jej realizacji.

25 Szczególne wyrazy podzięlkowania składam Rafałowi Lewandowskiemu, prezesowi Fundacji Asymetria, za możliwość przeprowadzenia kwerendy w archiwum Jerzego Lewczyńskiego i za zaszczepienie we mnie pasji do badania tej wyjątkowej dla polskiej sztuki postaci.

26 O. Ptak, Jerzozwierz. Portrety i autoportrety Jerzego Lewczyńskiego, Gliwice 2012, s. $17-21$.

27 Opis wybranych przykładów, por. W. Kobylińska-Bunsch, Utrwalić to, co niematerialne: fotografia jako (s)chronienie pamięci w polskich strategiach artystycznych XX i XXI wieku, w: Konserwacja zapobiegawcza środowiska 3. Dziedzictwo niematerialne i pamięć, red. J. Wysocki et al., Warszawa-Zielona Góra 2015, s. 170-171.

28 Więcej przykładów prac por. M. Janczyk, I. Święch, Otwieram i zamykam oczy. Prezentacja twórczości Jerzego Lewczyńskiego, Kraków 2006-2007, s. 30, 33-34.

${ }^{29}$ Pojęcie to - ze względu na swą niejednoznaczność i pojemność - budzi wśród teoretyków w pełni uzasadnione kontrowersje. Niemniej wykorzystanie kategorii „wernakularności” na potrzeby niniejszego studium nie wynika wyłącznie z jego niesłabnącej w Polsce popularności (m.in. za sprawą niedawnego wydania publikacji Clémenta Chéroux, por. C. Chéroux, Wernakularne. Eseje z historii fotografii, tłum. T. Swoboda, Warszawa 2014), ale przede wszystkim - z ciągle nierozwiązanego w naszym piśmiennictwie problemu nazewnictwa prac, które powstawały w opozycji do szeroko rozumianego obszaru „sztuki wysokiej”.

${ }_{30}$ M. Gołaszewska, Zarys estetyki. Problematyka, metody, teorie, Warszawa 1984, s. 27-30. Posługuję się tym terminem, gdyż dobitnie akcentuje on znaczenie interakcji pomiędzy odbiorcą a dziełem; wyjątkowa możliwość dialogu poprzez sztukę w programie Jerzego Lewczyńskiego wydaje się zaś szczególnie istotna. 
terystycznym piętnem: „zdobi” je siatka spękań i zarysowań. Niedoskonałości te, mimo swej wtórności wobec pierwotnego zapisu, Marta Przybyło-Ibadullajev nazywa wartością dodaną ${ }^{31}$. Stają się one przecież, jako świadectwa nieustannego obiegu artefaktu, jego integralnym elementem. Konsekwencją niesłabnącego zainteresowania oryginałem są jego nieuchronne (niechciane?) przekształcenia. O zjawisku tym w poetycki sposób pisał Wojciech Nowicki:

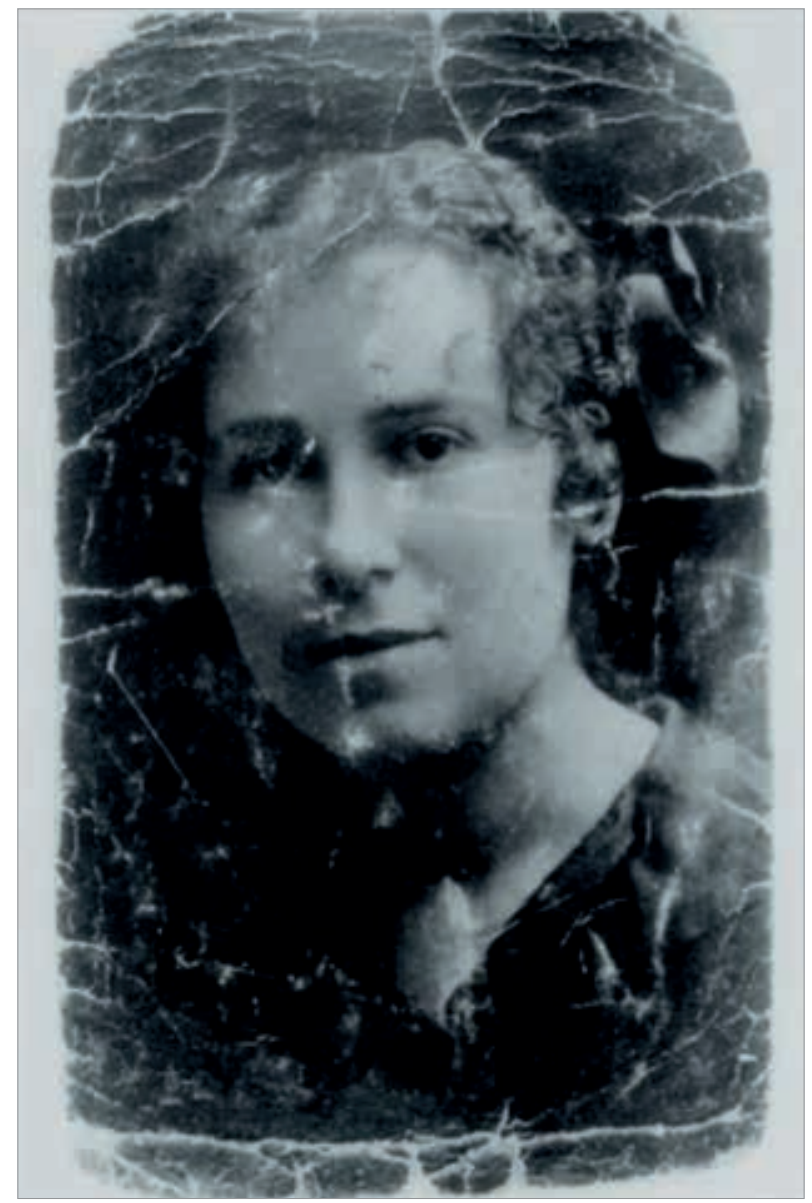

2. Jerzy Lewczyński, Znaleziona fotografia, 1980, czarno-biała odbitka żelatynowo-srebrowa. Własność prywatna. Dzięlki uprzejmości Galerii Esta

${ }^{31}$ M. Przybyło-Ibadullajev, Srebro w żelatynie, w: Emulsja, red. M. Przybyło-Ibadullajev, Warszawa 2015, s. 157. 
Trzeba tych skaleczeń; pleśniowa mgiełka jest konieczna, żeby się ukazało życie, które kiedyś było, żeby się zmaterializował czas dzielący wtedy od dziś. Za pomocą tak pokancerowanych zdjęć Lewczyński pisze własne dzieje fotografii, własne dzieje człowieka, dzieje siebie ${ }^{32}$.

Wątek ten podjęła również Dorota Dąbrowska, która analizując ustępy Fotoplastikonu pióra Jacka Dehnela, konstatuje: „To, co z punktu widzenia fotografii jako rzemiosła postrzegane jest jako defekt, «czynnik dyskwalifikujący» zdjęcie, zostaje zinterpretowane jako semantyczna dominanta"33. W poczuciu współczesnego odbiorcy niedoskonałości wręcz przywracają zdjęciom - w dobie monopolizacji sceny wizualnej przez wyretuszowane, sztucznie spreparowane obrazy, wprzęgnięte w świat konsumpcyjnej reklamy - aurę, której odmawiał im Walter Benjamin. Skazy i ułomności mogą nadać fotografiom cechy autentyzmu ${ }^{34}$, stanowią przeciwwagę dla „fałszywej mowy" ${ }^{35}$ pikselii $^{36}$. Przekonanie to staje się coraz częściej katalizatorem działań najmłodszej generacji twórców. Przykładowo, Max Alesky (ur. 1998) z kolektywu Nines_Magazine celowo zakopał taśmę $35 \mathrm{~mm}$, by znajdujące się $\mathrm{w}$ ziemi bakterie dokonały ingerencji w naświetlonym uprzednio negatywie. W konsekwencji jego zdjęcia z serii North Witham '43-'17 (2017) naznaczone są plamami świadczącymi o nieodwracalnym i niekontrolowanym przez artystę „zainfekowaniu” materiału fotograficznego (il. 3).

32 W. Nowicki, Odbicie, Warszawa 2015, s. 127.

${ }^{33}$ D. Dąbrowska, „Żeby się ukazało życie, które kiedyś było” - o znaczeniu materialności fotografii, w: Rzecz w kulturze, red. B. Pawłowska-Jądrzyk, D. Dąbrowska, Warszawa 2016, s. 45.

${ }^{34} \mathrm{O}$ afektywnym doświadczaniu fotografii, por. K.S. Calhoon, Personal effects: Rilke, Barthes, and the matter of photography, „MLN” (German Issue), 1998, 3(113), s. 617.

35 Analogiczne pragnienie powrotu do oryginału (faktycznego reliktu przeszłości) w miejsce silnie spopularyzowanych w ostatnich latach wirtualnych symulacji i nowoczesnych technologii multimedialnych - podnoszone jest także we współczesnym muzealnictwie, por. Muzeum faktów odczutych. Z Barbarą Kirshenblatt-Gimblett rozmawiają Jan Śpiewak, Zofia Waślicka i Artur Żmijewski, „Krytyka Polityczna” 2014, 40-41, s. 268-271.

36 Wątek ten podejmowali m.in. Rafał Drozdowski i Marek Krajewski, choć niektóre ich konkluzje dotyczące upadku społecznych rytuałów związanych z fotografią być może należą do aż zanadto pesymistycznych, por. R. Drozdowski, M. Krajewski, Za fotografię! W strone radykalnego programu socjologii wizualnej, Warszawa 2010, s. 170 . 


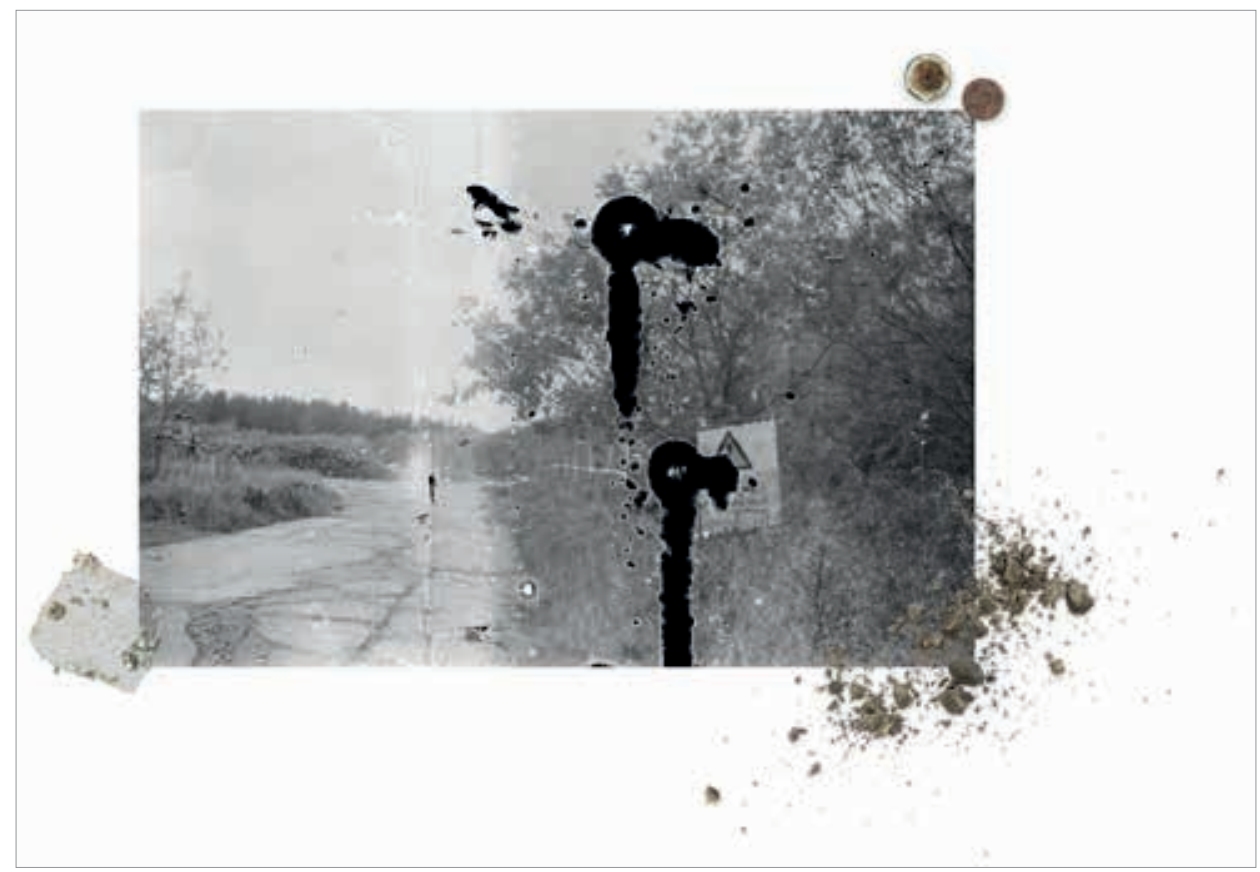

3. Max Alesky, z serii North Witham '43-'17, 2017, technika mieszana. Dzięki uprzejmości artysty

Wojciech Nowicki uczynił Jerzego Lewczyńskiego bohaterem wielu swych esejów ${ }^{37}$. Wykorzystuje on jednak kategorię materialności tylko przy opisie najbardziej rozpoznawalnej grupy zdjęć polskiego artysty, którą konstytuują „kalekie” i oszpecone wizerunki. W obszar ten doskonale wpisuje się na przykład słynny Tryptyk znaleziony na strychu (1971). Zarówno Nowicki, jak i Dąbrowska redukują potencjał „zwrotu ku rzeczom”, rozpatrując to zagadnienie jedynie przez pryzmat śladów postępującej atrofii poszczególnych fotografii. W moim przekonaniu zaś, w praktyce Lewczyńskiego niezwykle istotna okazuje się nieustanna fascynacja różnorodnymi rzeczami; każdą $z$ nich artysta śmiało uznaje za obiekt kulturowy. Postawę tego związanego z Gliwicami twórcy znamionowało bowiem, tak symptomatyczne dla koneserów i miłośników zbieractwa ${ }^{38}$, przywiązanie do materialnej formy rzeczy,

${ }^{37}$ Por. W. Nowicki, Jerzy Lewczyński. Pamięć obrazu, Gliwice 2012; W. Nowicki, Dno oka. Eseje o fotografii, Wołowiec 2010.

${ }^{38}$ Polska historia sztuki zawdzięcza postrzeganie kolekcji jako faktu antropologicznego przede wszystkim Krzysztofowi Pomianowi, por. K. Pomian, Zbieracze i osobliwości. Paryż-Wenecja. XVI-XVIII wiek, tłum. A. Pieńkos, Warszawa 1996, s. 16-17. 
które można dotknąć, poczuć specyfikę ich materiału - nawiązać z nimi bezpośrednią relację. Szczególną sympatią Lewczyński darzył stare negatywy, zwłaszcza te mające formę kruchej szklanej płyty; Ewa Domańska nazwałaby je zapewne "tworzącym ludzkie relacje darem" ${ }^{\prime 39}$.

\section{OD ZASIARCZONEGO SZKŁA DO ODBITKI WYSTAWOWEJ}

Istotnym dla historii polskiej fotografii efektem działań Jerzego Lewczyńskiego było ocalenie przed zniszczeniem i zapomnieniem dorobku autorstwa jego kolegi - Feliksa Łukowskiego (1919-1985). Fotografów tych połączyło wspólnie spędzone w powiecie tomaszowskim ${ }^{40}$ dzieciństwo. Przyczynkiem do działania o niemalże konserwatorskiej specyfice była dla Lewczyńskiego zarówno relacja oparta na przyjaźni i sentymencie, jak i czujność kolekcjonera, potrafiącego docenić coś, co inni przedwcześnie zlekceważyli. W roku 1986 Michalina Łukowska przekazała mu prace zmarłego męża - spuścizna ta liczyła ok. 1500 sztuk negatywów (szklanych, o formacie $6 \times 9 \mathrm{~cm}$ ). Do rąk Lewczyńskiego trafiły materiały w bardzo złym stanie zachowania, spowodowanym między innymi brakiem dostępu do wystarczającej ilości bieżącej wody podczas procesu wywoływania. Zasiarczone, zlepione i niekiedy zupełnie zniszczone, zostały przez Lewczyńskiego odczyszczone, zrekonstruowane i zabezpieczone. W roku 1992 doprowadził on do przekazania archiwum przyjaciela - unikatowego dokumentu życia Zamojszczyzny w latach 40. i 50. XX wieku - Muzeum Okręgowemu w Zamościu. Z wybranych negatywów Lewczyński osobiście wykonał około sześciuset powiększeń wystawowych. Złożyły się one na dużą ekspozycję noszącą tytuł „Było to 50 lat temu”41.

W konsekwencji Feliks Łukowski znany jest dziś jako autor bezcennej wizji wsi w Lubelskiem. Status rdzennego mieszkańca, bezpośrednio związanego z danym regionem, sprzyjał jego fotograficznemu przedsięwzięciu. Lokalna

${ }^{39}$ E. Domańska, Humanistyka nie-antropocentryczna a studia nad rzeczami, „Kultura Współczesna" 2008, 3, s. 16.

${ }^{40}$ Jerzy Lewczyński urodził się w Tomaszowie Lubelskim i tam też ukończył naukę w gimnazjum. W latach 40. XX w. mieszkał w Rachaniach, gdzie w latach 1942-1944 pracował jako listonosz. Po wojnie podjął studia na Wydziale Inżynieryjno-Budowlanym Politechniki Śląskiej w Gliwicach. Tam też pracował po studiach i ostatecznie osiadł na stałe w Gliwicach. Siemnice, w których urodził się Feliks Łukowski, to wieś położona w województwie lubelskim (powiat tomaszowski, gmina Rachanie). Rachanie i Siemnice dzieli odległość ok. $7 \mathrm{~km}$.

${ }^{41}$ Wystawa ta była też pokazywana w Lublinie, por. „Ocalone wspomnienia. Fotografie Feliksa Łukowskiego”, Akademickie Centrum Kultury "Chatka Żaka”, Lublin, 14 grudnia 2009 - 10 stycznia 2010. 
społeczność dopuszczała go do rejestrowania ważnych ceremonii i „rytuałów przejścia" - ludowego pejzażu kulturowego, do którego współcześnie możemy odbyć podróż już tylko poprzez fotografie ${ }^{42}$. Łukowski był w stanie oddać ówczesny genius loci rodzinnych Siemnic i ich okolic, pokazując wciąż żywą tam kulturę drewna. Dorobek Łukowskiego to jednak nie tylko dokumentacja ubiorów, wnętrz ubogich chat czy obrzędów. W centrum zainteresowań przyjaciela Lewczyńskiego znajdował się przede wszystkim portret. Łukowski był w stanie przezwyciężyć społeczne bariery, dzięki czemu aparat nie stawał się opresyjnym narzędziem wymierzonym w fotografowanego, ale sympatycznym towarzyszem prac w polu i życia towarzyskiego. Zamiast zesztywniałych i skonfundowanych postaci zamrożonych w nienaturalnym odrętwieniu, widzimy teatr min chłopca pozującego z maleńką sową bądź figlarnie spoglądające w kamerę rozchichotane kobiety.

Lewczyński poświęcił wiele sił i energii na zachowanie dorobku przyjaciela, gdyż urzekała go możliwość przeniesienia się - za jego sprawą - w czasie. Przywrócenie do życia twórczości Łukowskiego zakładało jednak ponowne i bezkompromisowe ucieleśnienie idei zmarłego kolegi w zupełnie nowej formie. Lewczyński sproblematyzował w tym przypadku kwestię autorstwa i obalił mit oryginalności dzieła sztuki, a zagadnienia te nie pozostały bez wpływu na ówczesne środowisko artystyczne ${ }^{43}$. Dzieła Łukowskiego rodzą się niczym feniks z popiołów wskutek autorytatywnej, wtórnie podjętej decyzji. Prace skromnego amatora $z$ Siemnic Lewczyński otrzymał przecież w formie negatywów. Wszelkie procedury związane z przygotowaniem finalnego dzieła na ekspozycję - takie jak powiększenie, kadrowanie, plamkowanie czy dopalanie - leżały w gestii kogoś innego niż sam twórca. Poprzez dobór określonego papieru (podłoża), decyzje dotyczące stopnia kontrastowości czy choćby formatu zdjęć Lewczyński zrealizował swoją własną wizję prac kolegi.

Przywracając historii sylwetkę Łukowskiego, Lewczyński obala utarte schematy i pojęcia metodologiczne. Sfatygowane i niechciane szklane płytki niewielkich rozmiarów - przedmioty uznane za zbędne po śmierci pierwotnego właściciela - nabierają nowych znaczeń w przestrzeni galeryjnej. Transpozycja zachodzi na linii: indywidualna przyjemność („zdejmowanie obrazów”

${ }^{42}$ Magdalena Szczypiorska-Mutor ów dualizm nazwałaby niepokojącym rozdarciem, por. M. Szczypiorska-Mutor, Praktyki fotograficzne i teksty kultury. Inwersja, metamorfoza, montaż, Warszawa 2016, s. 22.

${ }^{43}$ Lewczyński w latach 80. XX wieku gorąco propagował twórczość Łukowskiego w środowiskach artystycznych, por. J. Lewczyński, Feliks Łukowski - zapomniany fotograf ziemi tomaszowsko-lubelskiej, w: Fotografia artystyczna na terenach pogranicza w latach 1945-1987. Materiały z III Sympozjum w Szczecinie 13-15.11.1987, red. K. Łuczywek, Szczecin 1988, s. 91-107. 
ku własnej satysfakcji) - vs - masowa edukacja (rutynowe wycieczki szkolne na zamojską ekspozycję). Ukazując niebezpieczeństwa krzywdzących selekcji, odrzucających to, co lokalne i "swojskie”, artysta postuluje bezustanne rekonstruowanie i rekonfigurowanie wizualnego kanonu. Losy negatywów które uwiodły (jak by powiedział Alfred Gell ${ }^{44}$ ) i zmusiły Lewczyńskiego do działania - rozpoczęły się na śmietniku pamięci, zakończyły zaś - w muzeum historycznym.

Analogiczne w pewnym stopniu zjawisko, polegające na balansowaniu przez obiekt artystyczny pomiędzy bardzo różnymi formami, możemy zaobserwować na przykładzie Oceanu (1973) Zbigniewa Dłubaka. Często zapomina się, że w roku powstania dzieło to było upowszechniane przede wszystkim za sprawą mail artu grupy PERMAFO. Jego pierwotny charakter sytuował się zatem pomiędzy zaproszeniem na wystawę, drukiem ulotnym a "zwykłą" przesyłką pocztową. Ocean doskonale wpisywał się w globalny ruch postal art - obiegu sztuki działającego poza instytucjami kulturalnymi. Żółta koperta z określoną oprawą wizualną, logo i naklejonym znaczkiem pocztowym ma tu nie mniejsze znaczenie niż sama jej zawartość w postaci reprodukcji fotografii ${ }^{45}$. Zanna Gilbert, badaczka związana $z$ Getty Research Institute, twierdzi, że opakowanie w przypadku mail artów nie powinno być rozumiane jako „naczynie" ${ }^{46}$, które dopiero artysta wypełnia treścią, ale jest to samodzielny aktor, posiadający własną sprawczość. W bogatym dorobku Zbigniewa Dłubaka znajdziemy zatem nie tylko dzieła dotykające procesu percepcji i porządkującego ludzką rzeczywistość systemu znakowania (co nieraz podnoszono w literaturze), ale i problemu rzeczy ${ }^{47}$. Wielokrotnie złożone, wielkoformatowe płachty z dwiema reprodukcjami z serii Ocean wędrowały w torbie listonosza do różnych członków środowiska artystycznego. Towarzyszył im też krótki poetycki tekst Dłubaka. Nie uwidaczniał się tu jednak w pełni problem multiplikacji bardzo podobnych do siebie kadrów, jak w końcowej, wystawowej wersji. Dziś zatracił się już pierwotny kontekst tej pracy. Dzie-

${ }^{44}$ Alfred Gell używał tak sugestywnego i perswazyjnego języka w swym słynnym studium o praktyce tatuowania w Polinezji, por. A. Gell, Wrapping in images. Tattooing in Polynesia, Oxford 1999, s. 36.

45 Mail art grupy PERMAFO. Na kopercie, odręcznym pismem Jerzego Lewczyńskiego: „Ocean, 2.2.1973, Wrocław”, w środku reprodukcja dwóch widoków morskich Dłubaka oraz kartka A4 z wierszem artysty, w zbiorach Fundacji Asymetria w Warszawie.

46 Z. Gilbert, Networking regionalism: long-distance performativity in the International Mail Art Network, „TAREA” 2017, 4(4), s. 94.

47 Karolina Ziębińska-Lewandowska stawiała wręcz tezę o „unieważnianiu przedmiotu" przez Dłubaka niemal od początku jego zainteresowań fotografią, por. K. Ziębińska (Lewandowska), „Praktyka widzenia...”, s. 42. 
ło to kojarzymy z wysublimowanym, finalnym produktem galeryjnym - jako ciasno zestawione obok siebie odbitki, będące powtarzalnym zwielokrotnieniem specjalnie niewyróżniających się pod względem estetycznym widoków fal morskich i horyzontu.

W Oceanie skonkretyzowana zostaje postawa Dłubaka, widoczna już w jego wcześniejszym cyklu Krajobrazy (1949-1954) - artysta postuluje, by „przyjąć banał w najzwyklejszy sposób, bez akcentowania egzotyki codzienności" ${ }^{48}$. Zainteresowanie powszedniością nie przekładało się zatem, jak u Lewczyńskiego, na emocjonalne i zaangażowane do niej podejście. Gliwicki twórca z premedytacją pragnie zaś uruchomić drzemiące w nas pokłady sentymentalizmu.

\section{DZIENNIK WIZUALNY JERZEGO LEWCZYŃSKIEGO}

„Warto zapamiętać!” - szczere, spontaniczne hasło, zapisane niemalże dziecinnym pismem ${ }^{49}$. Te dwa słowa, zakończone pełnym emfazy wykrzyknikiem, to jedyna ozdoba zgrzebnej, matowej okładki szkolnego zeszytu w kolorze spłowiałego błękitu. Jerzy Lewczyński miejscem swych (być może najcenniejszych?) zapisków uczynił niemiły w dotyku - szorstki i matowy kajet. Używany w latach 80. i 90. XX wieku typ brulionu może dziś budzić pewien sentyment ${ }^{50}$, mimo zmechaconej oprawy i oczywistej nieatrakcyiności. Przekładając grube strony, przemierzamy wartki strumień codzienności artysty. Zanotowanym myślom i sentencjom towarzyszą świadectwa konsumpcyjnego "teraz" - kartki na jedzenie, spisywane odręcznie rachunki za zakupy i wycięte z prasy ilustrowanej zabawne slogany reklamowe. Oglądanie albumu jest dziś jednak doświadczeniem ambiwalentnym - nieprzyjemne uczucie bezradności (wiele danych trudno zinterpretować i zrozumieć, gdyż zostały wyrwane $z$ pierwotnego kontekstu) kładzie się cieniem na rosnącą ciekawość. Idąc tropem Marka Krajewskiego, można odważyć się na stwierdzenie, że dziennik niejako mści się na swoim nieproszonym czytelniku. Palce śmiałków wdzierających się w prywatną sferę artysty zostają naznaczone szarą warstwą kurzu; na szczęście nie czyha tu na nas tak zabójcza pułapka

48 Fragment wiersza Zbigniewa Dłubaka, element pracy Ocean.

49 J. Lewczyński, dziennik wizualny prowadzony w zeszycie szkolnym, ok. 1980, w zbiorach Fundacji Asymetria.

50 Tak należałoby zapewne tłumaczyć zainteresowanie współczesnych konsumentów analogicznymi wyrobami, regularnie pojawiającymi się na rynku internetowym. 
jak ta, w którą wpadł Adelmus z Otrantu, jeden z bohaterów Imienia róży Umberta Eco.

Na wytrwałego, zainteresowanego fotografią czytelnika czeka jednak nagroda. Nagle, spomiędzy bladych, słomkowych kartek wymyka się czarno-białe zdjęcie. Wyrafinowanie czystego bromu jest wręcz uderzające, na tle lichości zeszytowego papieru. Wysmakowana, aksamitnie gładka, matowa odbitka została niegdyś strącona z piedestału „sztuki wysokiej”. Musiała ukorzyć się i przebywać w towarzystwie porowatych kartek szkolnego brulionu. Trudno jednoznacznie rozstrzygnąć, czy sytuacja ta - jak chciałyby Elizabeth Edwards i Janice Hart - podnosi indeksalność ${ }^{51}$ samej fotografii, czy też raczej ją dewaloryzuje. Badacze koncentrujący swą uwagę na albumach fotograficznych niejednokrotnie odnotowują fakt, że odbitkom wtórują „auratyczne" - podnoszące ich znaczenie - obiekty. Zdjęcia często uzyskiwały dodatkową oprawę w postaci pamiątek, wycinanek ${ }^{52}$ czy dekorowanych okładek, nawiązujących do lokalnych surowców i tradycji ${ }^{53}$. Na tym tle album Lewczyńskiego wyróżnia się jako nietypowy, gdyż fotografia przestaje tu zajmować pozycję pierwszoplanową. Głównymi aktorami okazują się fragmenty gazet, kserokopie i kartki z notatkami. Artysta odrzuca wszelkie próby estetyzacji dziennika. Opisywany obiekt można zatem uznać za splot dwóch zupełnie różnych tradycji - zarówno wernakularnej, spontanicznej wytwórczości prywatnej, jak i międzywojennego (pełnego dowcipu i autodystansu) kolażu.

Analogiczne zainteresowania pojawiają się pod koniec lat 60. XX wieku u Stefana Wojneckiego, czego przykład stanowi prezentowana w roku 1969 w poznańskim Salonie PTF wystawa „Twarze”. Na odwrocie monumentalnych portretów zamieszczono materialne ślady codzienności - notatki, formularze, bilety (il. 4, 5). Same wizerunki zostały zaś okaleczone - podobizny

${ }^{51}$ W oryginale: „In this they extend the sense of vision and the indexicality of the photograph itself in a mutually reinforcing sign system", por. E. Edwards, J. Hart, Introduction: photographs as objects, w: On the Materiality of Images, red. E. Edwards, J. Hart, New York 2004, s. 12. Polski przekład tekstu por. E. Edwards, J. Hart, Fotografie jako przedmioty. Wprowadzenie, w: Badania wizualne w działaniu. Antologia tekstów, red. M. Frąckowiak, K. Olechnicki, Warszawa 2011.

52 Wzbogacanie wiktoriańskich albumów fotograficznych o kolaże czy akwarele było częstą praktyką wśród kobiet z wyższych sfer, por. np. Kate E. Gough, album fotograficzny, 56 stron, ok. 1870, Victoria\&Albert Museum, nr inw. 846-1963.

${ }^{53}$ F. Loughnane, "From daughters to sisters: photography and the institutional narratives of missionary and indigenous nuns", 2017, maszynopis udostępniony dzięki uprzejmości autorki, s. 3. 


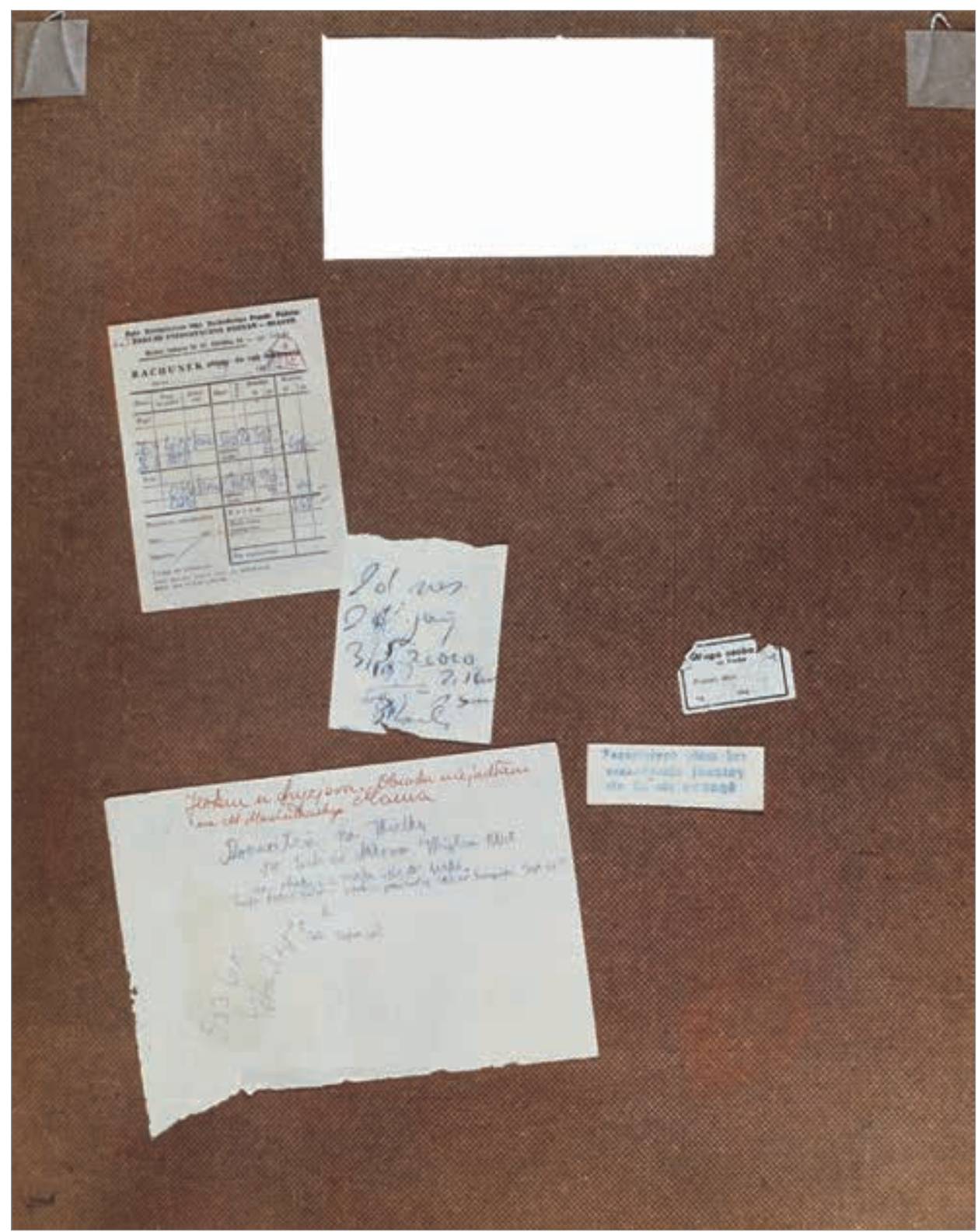

4. Stefan Wojnecki, fotografia z wystawy „Twarze”, 1969, widok odwrocia. Dzięki uprzejmości artysty 


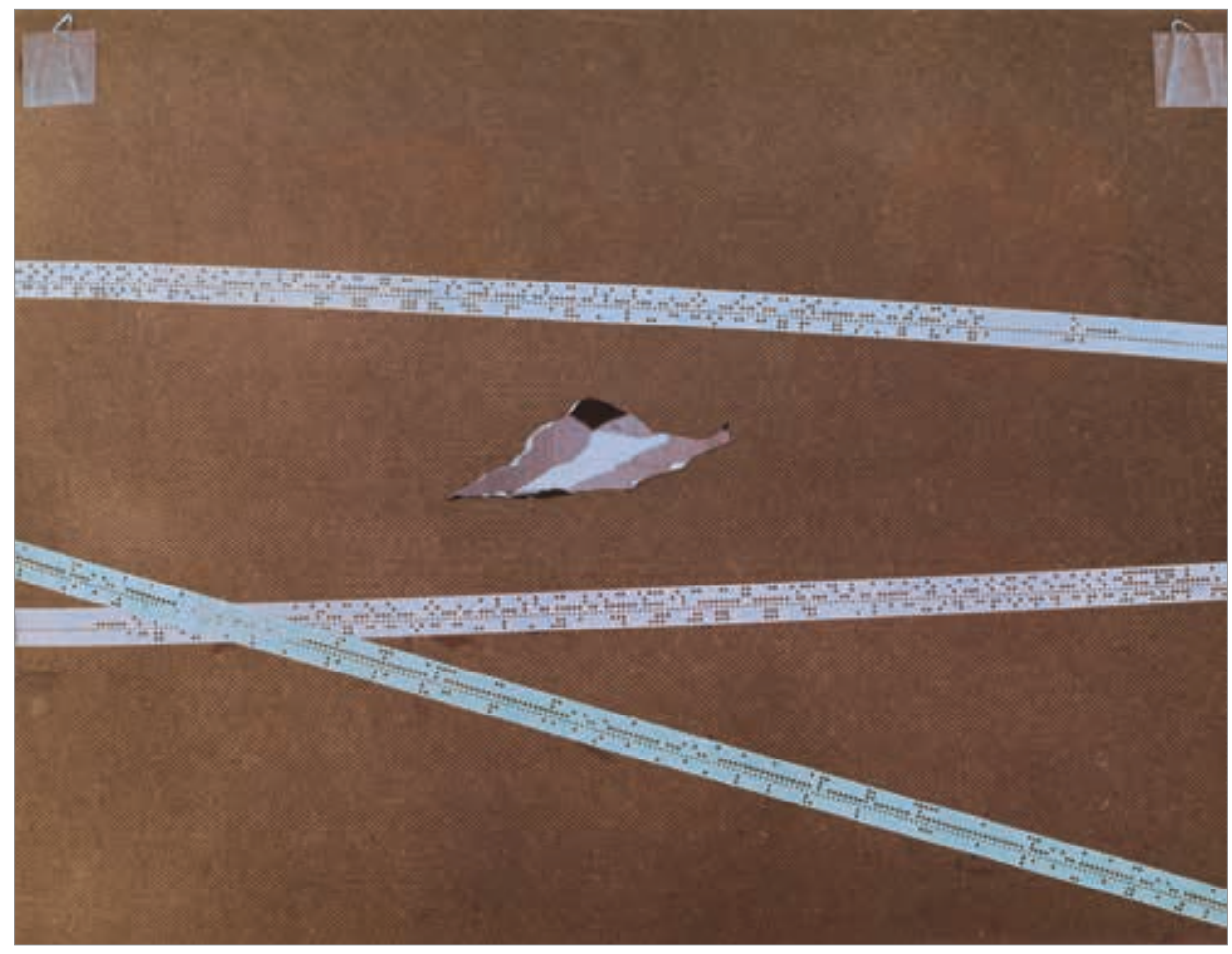

5. Stefan Wojnecki, fotografia z wystawy „Twarze”, 1969, widok odwrocia. Dzięki uprzejmości artysty

poszczególnych osób zastępowały puste, prostokątne otwory. Te swoiste „nie-widoki" ${ }^{54}$ wypełniali dopiero sami zwiedzający, stając się integralną częścią dzieła (il. 6). Całość uzupełniało panneau z papieru pakowego ze śladami butów, odciśniętych podczas wernisażu ${ }^{55}$. Sportretowanie (słowo jakże znamienne w kontekście tytułu ekspozycji Wojneckiego) jednostki wymagało wyjścia poza paradygmat ludzkiego ciała ${ }^{56}$ i koncentrację na - zwykle pomija-

${ }^{54}$ Rozwijam tu znaczenie pojęcia stosowanego przez Mariannę Michałowską, por. M. Michałowska, Nie-widoki. Fotograficzne narracje o cierpieniu, wystąpienie na ogólnopolskiej konferencji naukowej „Fotoesej 2: Widoki cudzego cierpienia”, zorganizowanej przez Zakład Poetyki Intersemiotycznej i Komparatystyki Mediów UKSW (Warszawa, 26 stycznia 2018).

55 Opis wystawy zob. A. Sobota, Impulsy i pęknięcia, w: Stefan Wojnecki - pęknięcia: ku symulacji, oprac. W. Makowiecki, M. Michałowska, M. Pawłowski, Poznań 1999, s. 11-12.

56 Por. A. Szyjkowska-Piotrowska, Po-twarz. Przekraczanie widzialności w sztuce i filozofii, Warszawa 2011, s. 26-41. 
nej - materii. Wojnecki nie ukazywał jednak rzeczy zgodnie z optymistyczną wizją Bjørnara Olsena ${ }^{57}$ jako przyjaznych obiektów konstytuujących tożsamość człowieka. Swoistym dopełnieniem cyklu „Twarze” były bowiem, mało dzisiaj znane, prace przedłożone przez artystę w roku 1971 Komisji Artystycznej Związku Polskich Artystów Fotografików ${ }^{58}$. Gdy Wojnecki zasłania oczy postaci taśmą komputerowąa bądź brutalnie rozdziela parę (zakochanych?) opornikami (il. 7a) ${ }^{60}$, rzeczy zostają wykorzystane jako czynnik alienujący, są świadectwem zerwania relacji społecznych.

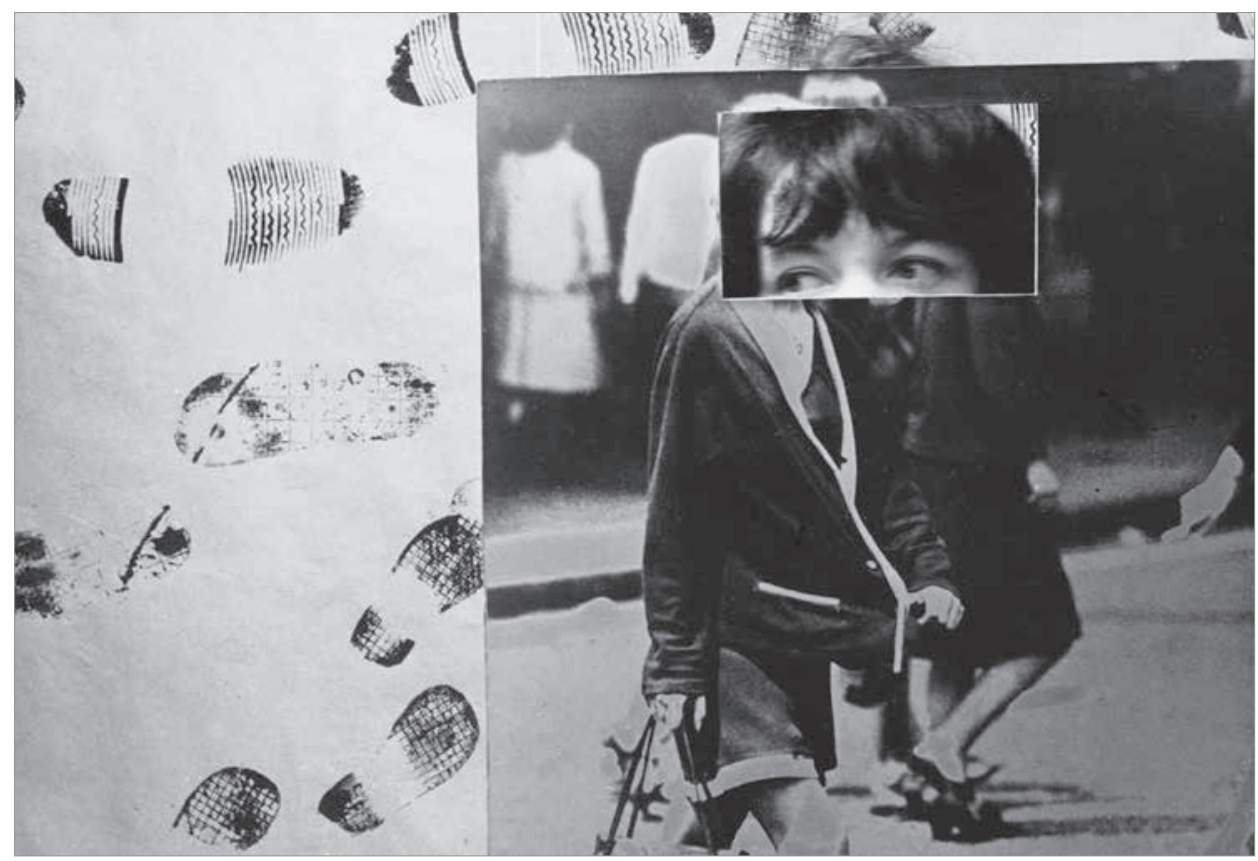

6. Dokumentacja wystawy „Twarze” Stefana Wojneckiego, salon PTF, Poznań, 1969. Dzięki uprzejmości artysty

57 B. Olsen, W obronie rzeczy. Archeologia i ontologia przedmiotów, tłum. B. Shallcross, Warszawa 2013, s. 19.

58 Ogromne podziękowania składam Pani Prezes Jolancie Rycerskiej oraz Panu Mateuszowi Skoniecznemu ze Związku Polskich Artystów Fotografików za udostępnienie mi wielu cennych materiałów $z$ archiwum ZPAF.

59 Zob. nietytułowane prace w teczce personalnej Stefana Wojneckiego, w zbiorach archiwum Związku Polskich Artystów Fotografików.

${ }^{60}$ Profesorowi Stefanowi Wojneckiemu, który nie tylko zechciał udzielić mi obszernego wywiadu, ale także przekazał na moje ręce liczne materiały i reprodukcje ze swego prywatnego archiwum, składam wyrazy serdecznych podziękowań. 

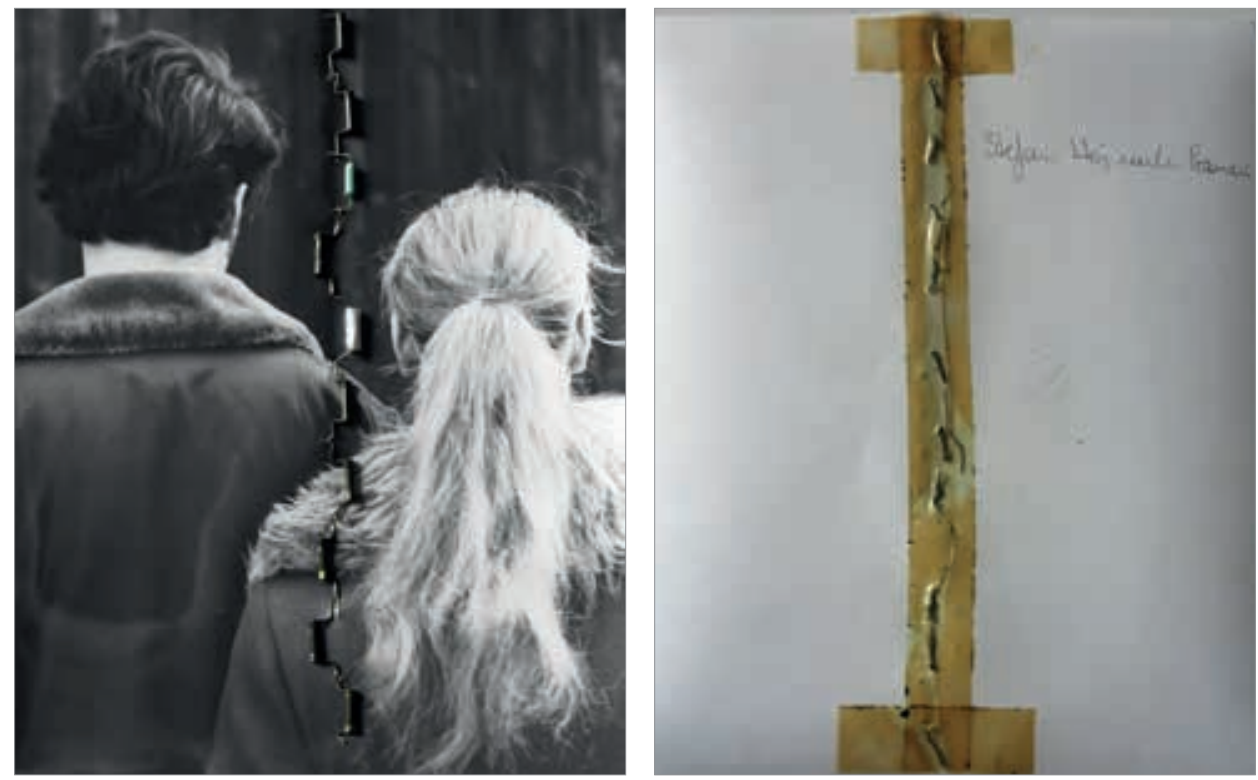

7. Stefan Wojnecki, (7a) praca bez tytułu, (7b) widok odwrocia, odbitka fotograficzna, technika mieszana, 1971. Teczka personalna Stefana Wojneckiego, w zbiorach archiwum Związku Polskich Artystów Fotografików. Dzięki uprzejmości Jolanty Rycerskiej, prezes ZPAF

Wojnecki w pewnym stopniu podziela zatem opinię Krajewskiego, zwracającego uwagę na „problematyczność przedmiotów" ${ }^{\prime \prime 1}$, a więc fakt, że bynajmniej nie są one uległe i w pełni od nas zależne, ale niezwykle często utrudniają realizację naszych planów czy założeń. Paradoksalnie, gest artysty zarazem dowartościowuje znaczenie tego, co codzienne i sensualne. Artysta pragnął odejść od koncepcji sztuki nieprzystępnej, nieuchwytnej i obcej, która - w jego przekonaniu - przestała być wystarczająca do opisu rzeczywistości ${ }^{62}$. Konieczne okazało się kreowanie narracji, której punktem wyjścia nie był abstrakcyjny konstrukt, ale to, co empiryczne (namacalne, używane, pozostające w nieustannym obiegu). Spektakularne, dopracowane technicznie powiększenia z cyklu Twarze dopełniał polifoniczny chaos prozaicznej rutyny w postaci kwitów, papierków i zapisków. Z kolei prace, na podstawie których Wojnecki ubiegał się o uzyskanie prestiżowego statusu członka ZPAF, zostały zdominowane przez elementy ze świata technologii i nauki: ciężkie matryce komputerowe, rezystory, perforowane nośniki do zapisu danych. Dziś taśma scalająca pozbawione tytułów od-

${ }^{61}$ M. Krajewski, Sq w życiu rzeczy. Szkice z socjologii przedmiotów, Warszawa 2013, s. 13.

62 W. Kobylińska-Bunsch, rozmowa ze Stefanem Wojneckim przeprowadzona w Poznaniu w dniu 16 czerwca 2017 roku, mps w zbiorach autorki. 
bitki i wgryzające się w ich substancję rzeczy jest już pożółkła i zesztywniała (il. 7b). Wyjmowaniu prac $z$ archiwalnych kopert towarzyszy niepokojący chrzęst zakrzepłej warstwy kleju, który - choć zgrabiały - wciążłączy zdjęcie i elementy pochodzące spoza fotograficznego porządku.

\section{PODSUMOWANIE}

Cały koncept metody Jerzego Lewczyńskiego opierał się na przywracaniu odrzuconych, zapomnianych rzeczy i odkrywaniu znaczenia ich mikrohistorii. W swej praktyce sięgał po zróżnicowane fotografie cudzego autorstwa: anonimowe, niechciane, wygrzebane ze śmietnika czy z popielniczki na Dworcu Centralnym. Posługując się określeniem Tadeusza Kantora, można stwierdzić, że to właśnie ta "realność najniższej rangi” ${ }^{63}$ tworzy zasadniczy kontekst naszej codzienności i - jak pisze Krajewski - „uczłowiecza jednost$\mathrm{kęq}^{\prime \prime 64}$. Obiekty zdegradowane, niepełniące już swych pierwotnych funkcji, dzięki gestowi artystycznej legitymizacji widzimy w zupełnie nowej perspektywie: jawią się one jako rzeczy pozwalające nam doświadczyć naszej własnej odrębności ${ }^{65}$. Lewczyński reprezentował głęboko humanistyczną, idealistyczną postawę, którą charakteryzowało przekonanie o magicznej aurze fotografii. Z pełnym przekonaniem i ekscytacją pisał:

Nie ma więc niepotrzebnych, nieznaczących fotografii! Wszystkie one budują pomost-continuum pomiędzy przeszłością a przyszłością ludzkiej egzystencji! ${ }^{66}$

W konsekwencji stał się specyficznego rodzaju kolekcjonerem, który w swoich wyborach nie kierował się żadnymi kryteriami czy rygorami. „Archeologia” $\mathrm{i}$ „,archiwum" to słowa nieprzypadkowo spotykające się w dyskursie towarzyszącym postaci Lewczyńskiego ${ }^{67}$. Pierwsze $z$ nich wskazuje na chęć poszukiwania i badania rzeczy, drugie - na potrzebę ich gromadzenia i przechowywania. Celem artysty nie było jednak katalogowanie rozumiane jako sposób okiełznania obiektów w okrzepłej, nieelastycznej strukturze, przypominającej praktykę muzealną. Lewczyńskiemu bliski był iście Foucaultowski koncept, w którym

${ }^{63}$ T. Kantor, Teatr śmierci. Teksty z lat 1975-1984, Wrocław 2005, s. 413-424.

${ }^{64}$ M. Krajewski, Przedmiot, który uczłowiecza..., „Kultura Współczesna” 2008, 3, s. 51.

65 Ibidem.

${ }^{66}$ Cyt. za: E. Łubowicz, Autoportret w negatywie. Oryginalność koncepcji fotografii w ujęciu Jerzego Lewczyńskiego, w: Archeologia fotografii. Prace z lat 1941-2005, red. K. Jurecki, I. Zjeżdżałka, Września 2005, s. 23.

${ }^{67}$ Jacques Derrida być może nazwałby Lewczyńskiego „archiwistą archeologicznym”, por. J. Derrida, Goraczka archiwum. Impresja freudowska, tłum. J. Momro, Warszawa 2016, s. 141. 
archiwum postrzegane jest jako rejon, gdzie nieustannie rozgrywają się procesy kumulacji, zanikania i przemieszczania ${ }^{68}$. Poruszając się po wrażliwej, dynamicznej tkance archiwum - którą Michel Foucault metaforycznie przyrównuje do piaszczystych wydm - odkrywamy coraz to nowe korelacje między poszczególnymi obiektami (wzniesieniami), jednocześnie odczuwając nieskończoność wysiłku interpretacyjnego i możliwość współistnienia różnorodnych narracji (tras). Każdy nasz gest czy ruch powoduje przesuwanie się (nakładanie, zacieranie) pewnych warstw wiedzy. Ów specyficzny obszar bynajmniej nie jest zatem bierny, neutralny i gładki. Jego charakter wyklucza możliwość stworzenia trwałej, linearnej narracji. W opinii Krzysztofa Pijarskiego, nieustanne zbieractwo stało się dla Lewczyńskiego działaniem artystycznym samym w sobie ${ }^{69}$. Marek Krajewski powiedziałby zaś, że pragnienie posiadania pozbawionego granic archiwum stało się niepokojącym nawykiem czy wręcz uzależnieniem od rzeczy ${ }^{70}$.

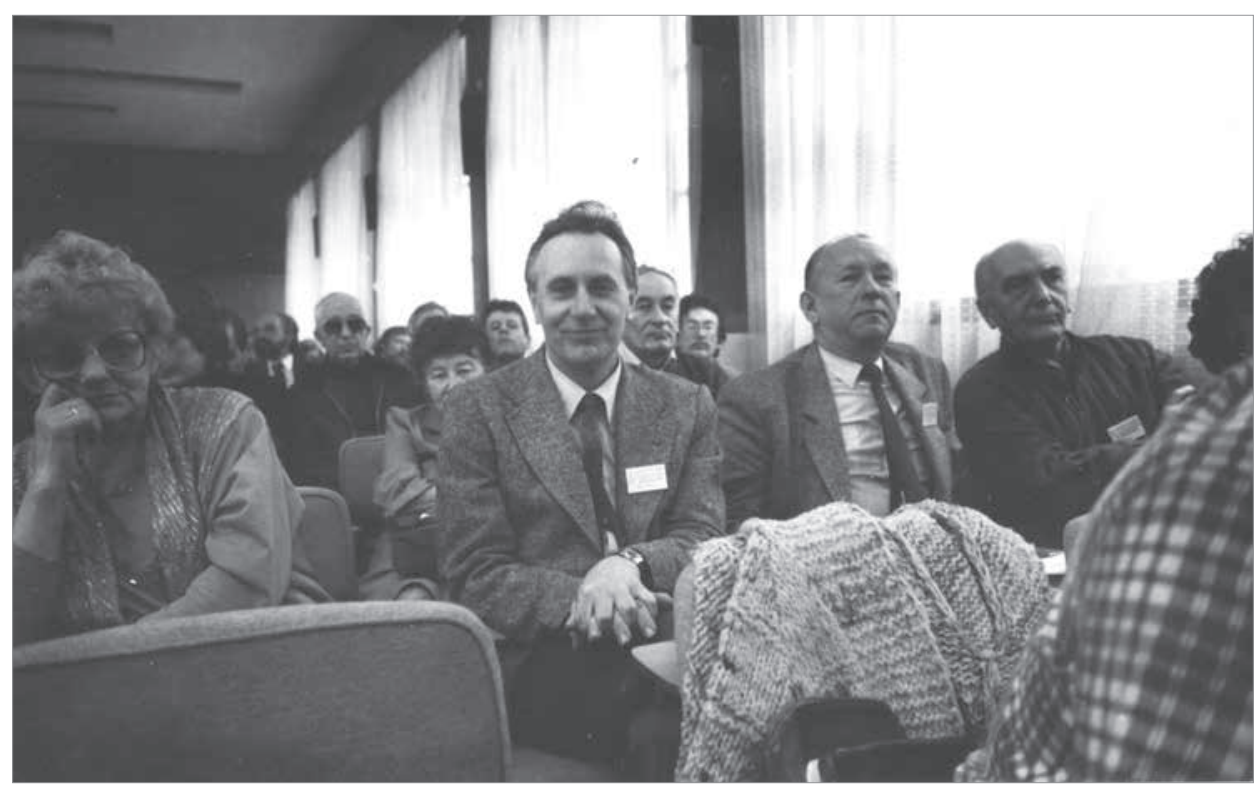

8. Autor nieznany, fotografia uczestników Gorzowskich Konfrontacji Fotograficznych, lata 80. XX wieku. W pierwszym rzędzie, od lewej: NN, Stefan Wojnecki, Jerzy Lewczyński, NN. Za Stefanem Wojneckim częściowo widoczna Zofia Rydet. Zdjęcie z prywatnego archiwum Stefana Woineckiego

${ }^{68}$ M. Foucault, Archeologia wiedzy, tłum. A. Siemek, Warszawa 1977, s. 164-167.

${ }^{69}$ K. Pijarski, Archeologia fotografii: czy można zarchiwizować gest?, „Kultura Współczesna" 2011, 4, s. 123-124, 134.

${ }^{70}$ M. Krajewski, Guma do żucia i papierosy. Dwa przedmioty, które lubię, w: W stronę socjologii przedmiotów, red. M. Krajewski, Poznań 2005, s. 130. 


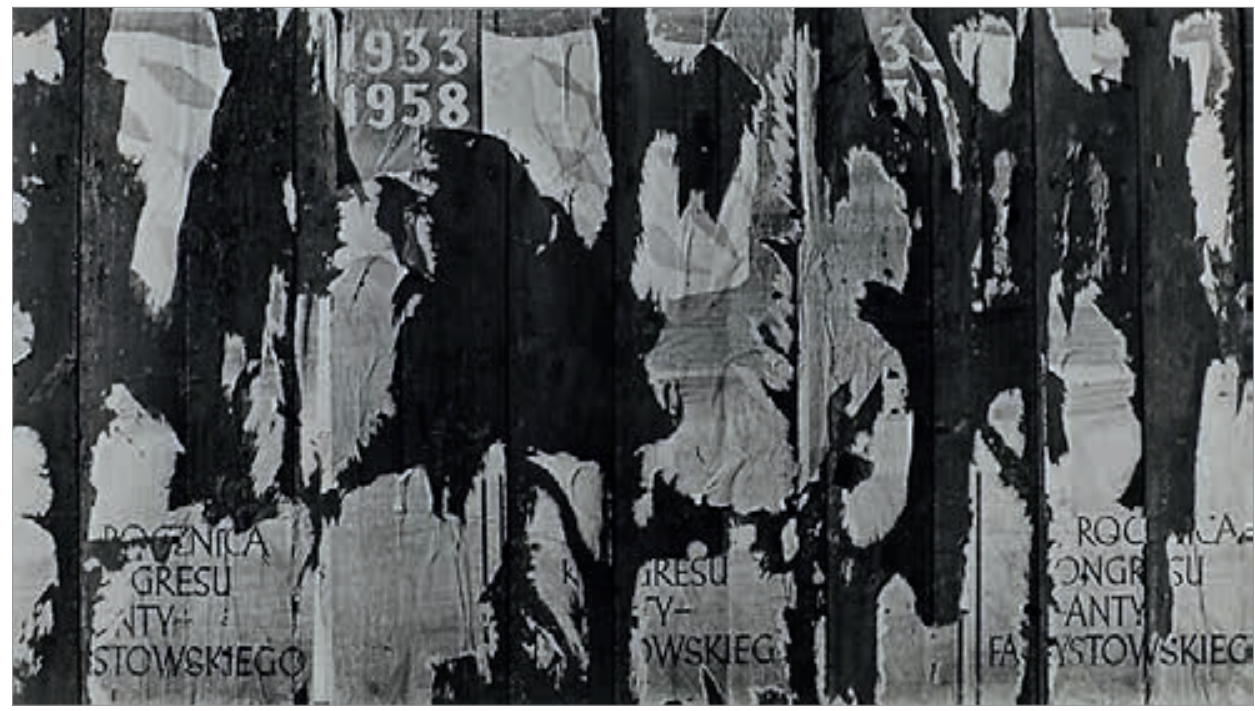

9. Jerzy Lewczyński, Guernica, 1958, czarno-biała odbitka żelatynowo-srebrowa. Teczka personalna artysty przechowywana w archiwum Związku Polskich Artystów Fotografików

Prace Jerzego Lewczyńskiego czy Stefana Wojneckiego zdają się wskazywać, że to właśnie materialność rzeczy jest dla nich jednym z podstawowych czynników znaczeniotwórczych ich dzieł. Wydrukowane na pospolitym papierze paragony, naznaczone czerwoną dominantą marki ORWO zdjęcia, spłowiałe ślubne fotografie nieznanych już ludzi czy kserokopie zdjęć prezentowanych niegdyś w galeryinym kontekście - wszystkie te rzeczy w opinii Lewczyńskiego stanowią mapę ludzkich spotkań, relacji, więzi i rozstań. Wyświechtane od przeglądania, znakowane autorską pieczątką bądź z namaszczeniem chowane do kopert, konstytuują repozytorium społecznych interakcji. Zamiast niemych przedmiotów do wizualnego smakowania Lewczyński ukazywał - wyprzedzając postulaty Bruno Latoura uczestników działań: przedmioty, które stawiają własne pytania ${ }^{71}$. Zarodek zasygnalizowanych w niniejszym tekście wątków być może odnajdziemy już w najwcześniejszych pracach Jerzego Lewczyńskiego z lat 50. XX wieku, które swym ekspresyjnym dramatyzmem i chropowatością zniszczonej faktury plakatów manifestują problem materii. Dynamiczna struktura fotografii i jej procesualność (nieustanna fizyczna cyrkulacja, wpływająca na zmienność jej charakteru i treści) przeciwstawiają się Barthes'owskie-

${ }^{71}$ B. Latour, When things strike back: a possible contribution of 'science studies' to the social sciences, „British Journal of Sociology” 2000, 1(51), s. 116. 
mu neomatowi naznaczonemu myśleniem o śmierci. Postulat „zapatrzenia w serce rzeczy ${ }^{\prime \prime 72}$ - o którym niegdyś pisał Zbigniew Herbert - wydaje się zaś stanowić doskonałą poetycką syntezę zainteresowań Jerzego Lewczyńskiego.

\section{BIBLIOGRAFIA}

Batchen G., Each wild idea. Writing, photography, history, London 2000

Calhoon K.S., Personal effects. Rilke, Barthes, and the matter of photography, "MLN" (German Issue), 1998, 3(113), s. 612-634

Chéroux C., Wernakularne. Eseje z historii fotografii, tłum. T. Swoboda, Warszawa 2014

Czartoryska U., Ikonosfera Zbigniewa Dłubaka, „Fotografia” 1967, 5, s. 101

Dąbrowska D., „Żeby się ukazało życie, które kiedyś było” - o znaczeniu materialności fotografii, w: Rzecz w kulturze, red. B. Pawłowska-Jądrzyk, D. Dąbrowska, Warszawa 2016, s. 33-47

Derrida J., Goraczka archiwum. Impresja freudowska, tłum. J. Momro, Warszawa 2016

Domańska E., Humanistyka nie-antropocentryczna a studia nad rzeczami, „Kultura Współczesna" 2008, 3, s. 9-21

Drozdowski R., M. Krajewski, Za fotografię! W stronę radykalnego programu socjologii wizualnej, Warszawa 2010

Edwards E., J. Hart, Introduction. Photographs as objects, w: On the Materiality of Images, red. E. Edwards, J. Hart, New York 2004, s. 1-15

Edwards E., Photography and the material performance of the past, „History and Theory" $2009,4(48)$, s. $130-150$

Edwards E., Objects of affect. Photography beyond the image , Annual Review of Anthropology" 2012, 41, s. 221-234

Foucault M., Archeologia wiedzy, tłum. A. Siemek, Warszawa 1977

Garztecki J., Prowokacje, „Kultura” 1967, 18(248), s. 10

Gell A., Wrapping in images. Tattooing in Polynesia, Oxford 1999

Gilbert Z., Networking regionalism. Long-distance performativity in the International Mail Art Network, „TAREA” 2017, 4(4), s. 84-96

Gołaszewska M., Zarys estetyki. Problematyka, metody, teorie, Warszawa 1984

Janczyk M., I. Święch, Otwieram i zamykam oczy. Prezentacja twórczości Jerzego Lewczyńskiego, Kraków 2006-2007

Kantor T., Teatr śmierci. Teksty z lat 1975-1984, Wrocław 2005

Kobylińska-Bunsch W., Utrwalić to, co niematerialne. Fotografia jako (s)chronienie pamięci w polskich strategiach artystycznych XX i XXI wieku, w: Konserwacja zapobiegawcza środowiska 3. Dziedzictwo niematerialne i pamięć, red. J. Wysocki et al., Warszawa-Zielona Góra 2015, s. 165-172

${ }^{72}$ Por. fraza rozpoczynająca niniejszy tekst. 
Kobylińska-Bunsch W., „Fotografia egzystencjalna” Zdzisława Beksińskiego, „Miejsce. Studia nad sztuką i architekturą polską XX i XXI wieku" 2016, 2, s. 59-83

Kordjak-Piotrowska (Kordjak) J., Polska fotografia awangardowa 2. połowy lat 50., w: Egzystencje, red. R. Szwander, Warszawa 2005, s. 5-17

Krajewski M., Guma do żucia i papierosy. Dwa przedmioty, które lubię, w: W strone socjologii przedmiotów, red. M. Krajewski, Poznań 2005, s. 129-135

Krajewski M., Przedmiot, który uczłowiecza..., „Kultura Współczesna” 2008, 3, s. $43-54$

Krajewski M., Sq w życiu rzeczy. Szkice z socjologii przedmiotów, Warszawa 2013

Kuryluk J., O mistrzach obiektywu - obiektywnie, „Kamena” 1962, 15(253), s. 7-8

Lachowski M., Awangarda wobec instytucji. O sposobach prezentacji sztuki w PRL-u, Lublin 2006

Latour B., When things strike back. A possible contribution of 'science studies' to the social sciences, „British Journal of Sociology” 2000, 1(51), s. 107-123

Lewczyński J., Feliks Łukowski - zapomniany fotograf ziemi tomaszowsko-lubelskiej, w: Fotografia artystyczna na terenach pogranicza w latach 1945-1987. Materiały z III Sympozjum w Szczecinie 13-15.11.1987, red. K. Łuczywek, Szczecin 1988, s. $91-107$

Łubowicz E., Autoportret w negatywie. Oryginalność koncepcji fotografii w ujęciu Jerzego Lewczyńskiego, w: Archeologia fotografii. Prace z lat 1941-2005, red. K. Jurecki, I. Zjeżdżałka, Września 2005, s. 21-24

Marek Piasecki. With care, red. E. Chorzępa, M. Piłakowska, Poznań 2017

Morton Ch., Photography and the comparative method. The construction of an anthropological archive, "Journal of the Royal Anthropological Institute" 2012, $2(18)$, s. 369-396

Muzeum faktów odczutych. Z Barbarą Kirshenblatt-Gimblett rozmawiają Jan Śpiewak, Zofia Waślicka i Artur Żmijewski, „Krytyka Polityczna” 2014, 40-41, s. $262-275$

Nowicki W., Dno oka. Eseje o fotografii, Wołowiec 2010

Nowicki W., Jerzy Lewczyński. Pamięć obrazu, Gliwice 2012

Nowicki W., Odbicie, Warszawa 2015

Olsen B., W obronie rzeczy. Archeologia i ontologia przedmiotów, tłum. B. Shallcross, Warszawa 2013

Olsen B., Z. Dziuban, Wszyscy jesteśmy archeologami, „Znak” 2015, wrzesień, <http:// www.miesiecznik.znak.com.pl/wszyscy-jestesmy-archeologami> [dostęp: 5 lutego 2018]

Pijarski K., Archeologia fotografii. Czy można zarchiwizować gest?, „Kultura Współczesna" 2011, 4, s. 121-135

Pomian K., Zbieracze i osobliwości. Paryż-Wenecja. XVI-XVIII wiek, tłum. A. Pieńkos, Warszawa 1996

Przybyło-Ibadullajev M., Srebro w żelatynie, w: Emulsja, red. M. Przybyło-Ibadullajev, Warszawa 2015, s. 157-160

Ptak O., Jerzozwierz. Portrety i autoportrety Jerzego Lewczyńskiego, Gliwice 2012

Scruton R., Fotografia i reprezentacja, w: Fotografia i filozofia. Szkice o pędzlu natury, red. S. Walden, tłum. I. Zwiech, Kraków 2013, s. 166-198 
Sibum O., Reworking the mechanical value of heat. Instruments of precision and gestures of accuracy in early Victorian England, „Studies in History and Philosophy of Science" 1995, 1(26), s. 73-106

Sobota A., Impulsy i pęknięcia, w: Stefan Wojnecki - pęknięcia. Ku symulacji, oprac. W. Makowiecki, M. Michałowska, M. Pawłowski, Poznań 1999, s. 10-15

Sobota A., Nowe horyzonty w nowych mediach. Zjawiska sztuki polskiej w latach 1945-1981, Wrocław 2017

Szczypiorska-Mutor M., Praktyki fotograficzne i teksty kultury. Inwersja, metamorfoza, montaż, Warszawa 2016

Szyjkowska-Piotrowska A., Po-twarz. Przekraczanie widzialności w sztuce i filozofii, Warszawa 2011

Wróblewska M., Fotografie ruin, ruiny fotografii 1944-2014, Warszawa 2014

Zagrodzka A., Fotografia subiektywna w sztuce polskiej 1956-1969, Lublin 2016

Zborowska A., Przedmioty w działaniu, „Widok. Teorie i praktyki kultury wizualnej” 2014, 6, <http://pismowidok.org/index.php/one/article/view/200/330> [dostęp: 5 lutego 2018]

Ziębińska (Ziębińska-Lewandowska) K., „Praktyka widzenia. Twórczość fotograficzna Zbigniewa Dłubaka w latach 1947-2000", praca magisterska napisana pod kierunkiem prof. Marii Poprzęckiej, Instytut Historii Sztuki Uniwersytetu Warszawskiego, Warszawa 2001

Weronika Kobylińska-Bunsch

Instytut Historii Sztuki

Uniwersytet Warszawski

\section{MATERIALITY OF THE LIGHT RECORD. \\ ON THINGS IN JERZY LEWCZYŃSKI'S OEUVRE}

\section{Summary}

The popularity of Jerzy Lewczyński (1924-2014) coincided with the academic interest in the problem of archive, corresponding to Lewczyński's program of the "archaeology of photography," developed in the 1970s. Lewczyński's idea consisted in restoring Kantor's "reality of the lowest rank," i.e. the rejected microhistories hidden in the anonymous and the forgotten or taken out of an ashtray at the Warsaw Central train station. Today, however, one tends to forget that Lewczyński's gesture of artistic legitimization did not aim at giving new meanings, but above all at blurring the boundary between everyday items and those which emerged from some kind of "aesthetic situation" (Maria Gołaszewska). This aspect of his art can be seen, e.g., in his visual journal, where the artist included objects of particular importance - next to Xerox copies of his own works or works of other artists, he placed also shopping receipts. Lewczyński equaled the value of cheap receipt paper with the noble velvety quality of bromine papers. He did not reduce his collected items to their aesthetic function, having rejected the insti- 
tutionalized idea of the artifact as a work of art to enjoy by the audience. Anticipating the postulates of Bruno Latour, instead of showing objects appropriated by the power of the gaze, he presented actors: things that asked questions on their own.

Keywords:

archaeology of photography, materiality of photography, Polish photography, Jerzy Lewczyński, archive, social art history 
